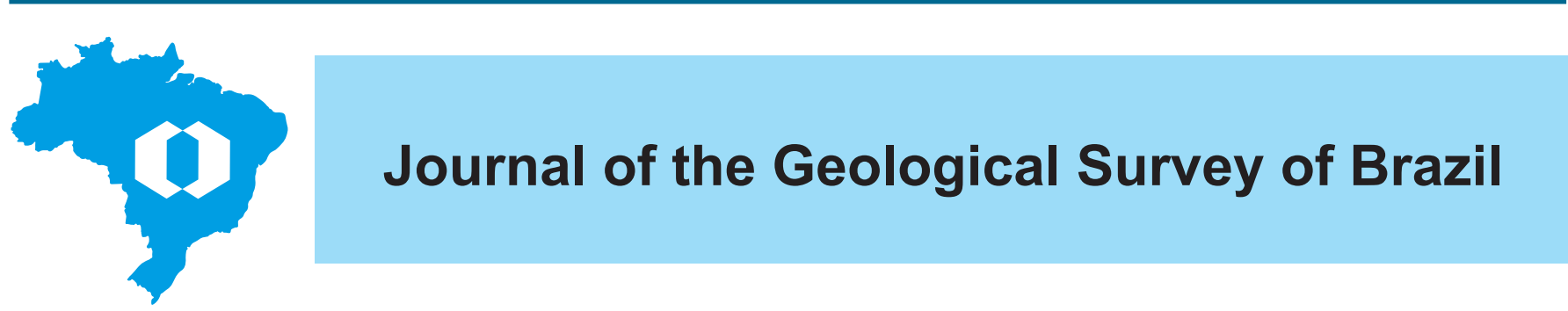

\title{
Geoethics and geoconservation: integrated approaches
}

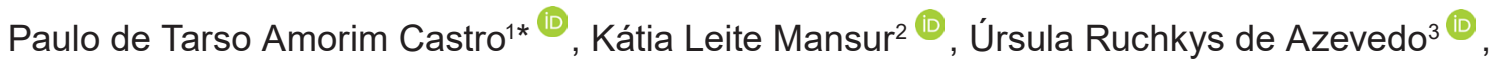 \\ Rosely Aparecida Liguori Imbernon ${ }^{4}$ ()
}

${ }^{1}$ Universidade Federal de Ouro Preto, Escola de Minas, Departamento de Geologia, Ouro Preto, Minas Gerais, Brazil, CEP: $35400-000$.

2Universidade Federal do Rio de Janeiro - UFRJ, Instituto de Geociências, Departamento de Geologia, Av. Athos da Silveira Ramos 274 - Cidade Universitária Ilha do Fundão, Rio de Janeiro - RJ - Brasil - CEP. 21.941-916

3Universidade Federal de Minas Gerais. Av. Antônio Carlos, 6627, Pampulha - Belo Horizonte - MG, Brazil, CEP: $31270-901$.

${ }^{4}$ Universidade de São Paulo, Instituto de Geociências, Rua do Lago, 562, São Paulo - SP, Brazil, CEP: 05508-080

\section{Abstract}

The last thirty years have seen major changes in the relationship between humanity and the Earth system. The United Nations Conference on Environment and Development, RIO 92, brought both the society and the scientific community, in general, the perception of the need for an integrated view of the Earth and the meaning of the irresponsible intensity of the exploitation of natural resources, by definition restricted to the planet. From this convention emerged integrative initiatives in the natural, human, and social sciences. Two fields of geoscientific knowledge have emerged: geoconservation and geoethics. Geoconservation, more widespread today, deals with the conservation of outcrops, rocks, minerals, and fossils of geoscientific relevance and their forming processes, spreading its values both at the scientific, educational, and tourist levels. Geoethics, for its part, is concerned with the relationship between humanity and the Earth system, seeking to act in education as well as in the professional practice of geoscientists. Between both fields, there is an overlap of action zones. In these overlapping zones, intensive rock sampling in important outcrops from the point of view of geoconservation is discussed. What is in focus is the responsibility of geoscientists to preserve the integrity of emblematic outcrops in the construction of knowledge about geohistory. Equally important are the way and quality of the dissemination of information on the elements of geodiversity and the implications for society, in terms of natural disasters and those resulting from the anthropic activity. This article presents an analysis of the interaction between these fields in the educational agenda of universities and professional associations of geoscientists.
Article Information

Publication type: Research papers

Received 2 November 2020

Accepted 21 December 2020

Online pub. 5 February 2021

Editor: M.G.M. Garcia

\section{Keywords:}

Geoconservation;

Ethics for geoscientists;

Geoeducation;

Dissemination of geoscientific information.

${ }^{*}$ Corresponding author

Paulo de Tarso Amorim Castro

E-mail address: paulo_de_tarso@ufop.edu.br

\section{Introduction}

"Land, like Odysseus' slave-girls, is still property. The land relation is still strictly economic, entailing privileges but no obligations." Such were the words of Aldo Leopold (1949) at the dawn of conservationist thinking. Although he was writing in respect to the use of land, and not the Earth system, the basis of the human relationship with the Earth can no longer ignore the necessary obligations and remain centered only on the enjoyment of its components, understood as resources for humanity.

According to data from the Population Division of the Department of Economic and Social Affairs of the United Nations Secretariat (United Nations 2020), in July 2020, planet Earth reached around 7.8 billion humans, double the human population in 1973. According to Roser (2019), if the exponential growth of the world population continues within the current parameters, it is forecast that we will reach 11 billion inhabitants on the planet by 2100 . Anthropic action on the Earth System has promoted profound modifications since the beginning of the industrial period. It is widely known that the emission of gases that increase the greenhouse effect and growth in the production of genetically modified foods generate ever more evident risks of water scarcity, increased food insecurity and impacts on ecosystems. In the same way, the constant demand for more energy, rawer materials and other inputs has promoted a process of global environmental degradation, which requires a collective scientific effort in search of an acceptable and controlled level of consumption.

However, this relationship has been profoundly transformed over the last two centuries. Castro and Ruchkys (2017) recognize five different phases in the relationships of human society with the Earth system; these phases coexist until today. The first phase is marked using geomaterials as resources to satisfy its survival needs. There are countless types of lithic artifacts in prehistoric archeological sites scattered throughout the world, indicating the utilitarian relationship of geomaterials as resources by human groups. 
Subsequently, there appeared phases of understanding of the Earth's nature, concerns regarding the use of finite natural resources, and that of environmental degradation. The last of the five phases appeared at the beginning of the 1990s, its historical milestone being the United Nations Conference on Environment and Development (UNCED), RIO-92. The seeds of Geoconservation and Geoethics are in this phase, which, despite being contemporaneous and along the same lines, differ on certain points.

Thus, based on conceptual analysis and selected case studies, the present article has the main aim of presenting the possible interactions between Geoconservation and Geoethics in order to contribute to their theoretical formulation, which remains incipient.

\section{Methodological standards}

According to Mogk et al. (2018), solutions for the confrontation of great future challenges involve integration between different academic fields, representing four basic procedures:

1. Knowledge of the Earth system and its functioning;

2. Understanding of social and cultural values, and their dynamic;

3. Understanding of economic realities; and

4. Awareness of the philosophical approaches that address human actions that generate catastrophic and negatively irreversible impacts on human existence and on ecosystems.

This future scenario places us before various problems and dilemmas, in different areas of knowledge, for which we must question whether geoscientists are prepared to intervene. Based on this reflection, it is essential to discuss the ethical aspects involved in human action within the scope of the Earth system.

In recent years, the importance of conserving abiotic nature gained recognition, which has led to the theoretical and practical development of this area. Considering this context, a geoethical approach associated with geoconservation may assist in society's understanding of the value of abiotic nature, and in the formulation of more informed strategies for the conservation of geodiversity and geoheritage (Allan 2015).

Thus, terms that are applied to geosciences and characterized by the geo prefix, such as geodiversity, geoheritage, geoconservation, geotourism, geopark, and geoethics have appeared and been widely divulged over the last 30 years. According to Ruchkys et al. (2018), the geo prefix brings the perspective of a systemic view of the Earth, with its use being associated with the Gaia hypothesis postulated by Lovelock (1995), which considers that the planet and all its biotic and abiotic elements constitute a unique system of interactions, which present an integrated dynamic of functioning. The inspiration for the name of the theory comes from Greek mythology where Gaia, Geia or Ge (Гaía in Greek) is the Mother-Earth.

Geoconservation can be defined as a set of techniques and measures that aim to guarantee conservation (including rehabilitation) of geological heritage and geodiversity, based on analysis of their intrinsic values, vulnerability and degradation risk (Carcavilla et al. 2007). Brilha (2016) inserts the protection of ex situ geodiversity into the concept when it holds scientific, educative, and/or touristic value.

Peppoloni and Di Capua (2015) present the etymology of the word geoethics, asserting that the prefix "geo" refers to
"Gaia". In ancient Sumerian, the meaning is "house, place of habitation". Thus, "geo" refers to the place where humans live. The word "ethics" has a double meaning: firstly, it contains a sense of belonging to a social dimension of life; secondly, it is related to the individual sphere of each person. Both in the social and individual field, the etymological root of the word "ethics" demands that human beings face their responsibilities.

According to the definition on the IAPG - International Association for Promoting Geoethics Website (Di Capua and Peppoloni 2019), "Geoethics consists of research and reflection on the values which underpin appropriate behaviors and practices, wherever human activities interact with the Earth system. Geoethics deals with the ethical, social, and cultural implications of geoscience knowledge, education, research, practice, and communication, providing a point of intersection for Geosciences, Sociology, Philosophy and Economy". The authors add that "Geoethics represents an opportunity for geoscientists to become more conscious of their social role and responsibilities in conducting their activity, being a tool to influence the awareness of society regarding problems related to geo-resources and geo-environment".

Manyimportant points unite Geoethics and Geoconservation. One such point refers to the need to divulge geoethical postures in relation to sample collection for laboratory analyses with the aim of geosite conservation (Mansur et al. 2017), the popularization of science, definition of load capacity at geosites, and even occasional bans on visitation when such sites are considered fragile.

Thus, according to Bobrowsky et al. (2017), from the perspective of geoscientists, there are four levels of responsibility to be considered in Geoethics: (1) in the individual conducting of the work of each geoscientist; (2) in multidisciplinary cooperation with other colleagues; (3) with society, aiming to minimize environmental impacts and respecting the natural dynamic; and (4) with the Earth system, which should be conserved for future generations.

For Drąsutè et al. (2019), the integration between Geoconservation and the principles of Geoethics can be defined by the social responsibility and ethical attitude of geoscientists. Thus, the application or relationship of geoethics with geoconservation occurs mainly at level (3) and level (4), considering the Earth system and its abiotic elements (geodiversity) as assets to be conserved (especially geoheritage) for the next generations.

Considering geoconservation from a geoethical perspective, we should bear in mind two central questions: (1) how this approach has been carried out at a level of scientific production and in education in Geosciences; and (2) the role that geoconservation may have in the promotion of geoethics. As Peppoloni and Di Capua (2015) emphasize, Geoethics may represent a new way of thinking and interaction with the Earth system, and a new way of addressing global problems. In this case, Geoconservation may benefit from these principles while also helping to promote them.

"Natural capital", according to the definition given by the World Forum on Natural Capital (2017), involves "the world's stocks of natural assets which include geology, soil, air, water and all living things". This definition, although not the only one, is one of the most important and includes geodiversity, recognizing its place as the basis of the planet (Gray 2019).

Within this context, when we refer to natural systems, we identify a high degree of complexity and natural or 
anthropic processes, which often promote irreversible environmental changes.

The human concern with environmental impacts has a long history (Mooney and Ehrlich 1997), which has intensified since the 1960s. In May of 2019, an international agreement in the scope of the Subcommission on Quaternary Stratigraphy (2019) indicated that we are experiencing a new geological period the Anthropocene. This finding ratifies that human beings have become an important threat to natural capital, which has driven the search for development and consumption models defined based on sustainable management of natural capital.

Mansur (2018) highlights that the definition of natural, in the popular sense, points to "everything that was not produced by man", distancing human beings from their essence as part of nature, whereby "One is not part of the space of the other. With reciprocal externalities, nature and man exclude each other and oppose each other. Born is the basis of the man-environment dichotomy characteristic of modern thought" (Soares 2008, pages 4 and 5). However, a movement appeared at the end of the 20th Century, which, driven by the weight of thousands of years of thought distancing man from nature, saw human beings start to understand that they will need to unify the "world of man" with the "world of nature" (Carvalho 1991) to live a healthier life and glimpse a more optimistic future.

Thus, as we come to complete two decades of the 21st Century, the growing use of natural resources has awakened in society questions that involve planetary sustainability. This is not only in issues related to the exhaustion of Earth's resources and impacts resulting from intense anthropic action on a local and global scale but also protection before processes of the Earth's dynamic - natural disasters (Peppoloni and Di Capua 2015).

Within this scenario, the methodological approach consists of the theoretical analysis of two fields of knowledge, above all, their connection with society and convergences with sustainable development initiatives. The methods were developed in four stages: 1) analysis of the principles of Geoconservation; 2) analysis of the principles of Geoethics; 3) points of convergence between the two; and 4) practical applications with examples.

To that end, the proposition involving Geoethics and Geoconservation is associated with X-disciplinarity, as scientific knowledge should transpose epistemological limits and dialogue with other understandings, in different forms of knowledge production, to go beyond the academic environment, as presented in definitions of "transdisciplinarity" (Castro 2019).

Also, according to the same author, $\mathrm{X}$-disciplinarity makes us "think with greater precision on our academic practice, on research, on teaching and on related activities", which Geoethics and Geoconservation propose in the field of Geosciences.

"Even more importantly, we do this to force ourselves to leave the comfort zone of our disciplinary spaces, which frequently operate as sterile, airtight compartments, and stimulate us to contribute to development in the form of producing knowledge guided by the principles of complexity, relational and dialogic thought, in the search to overcome fragmentation and promote greater reintegration of the sciences". Castro (2019).

Thus, by adopting X-disciplinarity to stimulate individual and collective critical reflection on the knowledge processes in which we are involved, we establish, in principle, a question on the meaning of the numerous prefixes we seek to introduce into disciplinary interactions, such as cross, inter, multi, trans, and post-disciplinarity, among many others.

\section{Results}

\subsection{Philosophical bases of Geoconservation and Geo- ethics (their common origin) and the events that have culminated in the present moment.}

Geoscientists, as professionals and scientists with specific competencies in the understanding and study of the dynamic of the planet, have a fundamental role in society. According to Peppoloni and Di Capua (2012), when "discussing the ethics in relation to Geosciences, Geoethics, establishes considering the social implications of geological research and practice, as an indispensable requirement for geoscientists".

Geoconservation or conservation of geodiversity can be defined as actions taken with the aim of conserving and improving characteristics, processes, places, or elements, particularly geological or geomorphological, related to geodiversity. This generally involves working with natural changes to maintain a characteristic of interest, for example, maintaining the clear exposition of a stratigraphic sequence on a cliff undergoing an erosive process, despite the erosion. It does not mean stopping the erosion and freezing the exposition in time. Successful geoconservation often depends on understanding and valuing resources that need to be conserved, which is why geoconservation actions include promotional and awareness-raising activities on the desired object of conservation (Burek and Hope 2006).

Some geoconservation principles can be found in the International Declaration of the Rights of the Memory of the Earth (Digne - FR 1991): "Just as an ancient tree retains the record of its life and growth, the Earth retains memories of the past inscribed both in its depths and on its surface, in the rocks and in the landscape, a record which can be read and translated; We have always been aware of the need to preserve our memories - i.e. our cultural heritage. Now the time has come to protect our natural heritage, the environment. The past of the Earth is no less important than that of human beings. Now it is time for us to learn to protect, and by doing so, to learn about the past of the Earth, to read this book written before our advent: that is our geological heritage".

Thus, geoconservation principles include recognition of the historical records of the evolution of the Earth as geoheritage, to be protected and safeguarded for future generations. Stephens (2020) emphasizes that geoconservation is associated with a new social responsibility related to the sustainable development and valuing of geodiversity resources from the heritage point of view, as originally argued by Henriques et al. (2011).

The relationships between Geoconservation and Geoethics occur in the historical, philosophical and, to a certain extent, temporal spheres (Figures 1 and 2). In temporal terms, the 1990s represent an important milestone. The term geoethics was introduced in 1991 by Nemec and the International Declaration of the Rights of the Memory of the Earth was elaborated in the same year. The concern with the conservation of geodiversity resources, their finitude and guarantee of use for future generations are common 
points. It is important to highlight the UN proclamation of the International Year of Planet Earth in2008 (Mulder et al. 2006) and the International Year of Global Understanding, in 2016 (Werlen et al. 2016).

From the historical perspective, the importance of the advance in geological knowledge in the 19th century is clearly noted, whereby the scientific bases for observation of the planet were introduced, bringing relevance to those elements that stood out for representing patterns and/or characterizing rarities. While the philosophical basis for Geoethics was introduced in the first half of the 20th century, Geoconservation demonstrated this advance in discussions on environmental sustainability in the 1970s. For both, the 1990s, represented by the temporal milestone of Rio 92, are crucial. The concept of geoethics, and the International Declaration of the Rights of the Memory of the Earth were introduced in 1991. In Brazil, discussions on geoconservation came before those on geoethics.

\subsection{The values and objectives of Geoconservation and Geoethics and the overlap zone between them}

Figure 3 presents a scheme of common paths to Geoconservation and Geoethics and the overlap zone between the two themes. In the overlap, the theme of sampling demarcates the field of the direct action of the geoscientist in the individual conducting of their work, while uses, the availability of resources for future generations and communication with society refer to their social responsibility and responsibility for the environment (Bobrowsky et al. 2017). This shows that the geoethical posture is also essential for Geoconservation

In the field of Geoconservation, the importance of the intrinsic value of geodiversity is clear, whereby the simple existence of geological heritage defines its relevance. For Geoethics, on the other hand, its importance to society is evident, and it clearly shows the direct relationship between Geoethics and natural and anthropic disasters.

\subsection{National and international examples of good and bad relationships between the scientific community and society from the perspectives of Geoconservation and Geoethics}

It is a fact that, in general, geoconservation has been focused primarily on rural and/or natural environments, which involve natural heritage: "education for the Earth System, incorporated into practices in Education for Sustainability, is a critical tool in the construction of knowledge and values by rural communities. It contributes to transforming current practices impacting the environment, to raising the awareness of producers as agents responsible for the recovery and maintenance of environmental systems, and valuing the environmental services provided by the systems" (Penkaitis et al. 2020).

However, in the urban scenario, beyond discussing questions that involve sustainability and quality of life, we should also evaluate the role of geodiversity and geoconservation within the scenario of environmental degradation: "upon recognizing the fundamental and vital value to humanity arising from geodiversity, possible impacts and threats to the same are distinguished, which occur both at local scales and in wider contexts. Normally underestimated or not even recognized, activities that result in the loss or degradation of geodiversity, due to both natural processes and those induced by humans, are abundant" (Fontana et al. 2015).

Given the great environmental debates occurring in the first two decades of the 21st century, it is evident that there is a need for conservation and protection of ecosystems, as well as of the geoheritage and forest remnants in urban areas. Various examples of geoconservation in urbanized areas have been the object of studies, both in small-scale urban centers and in

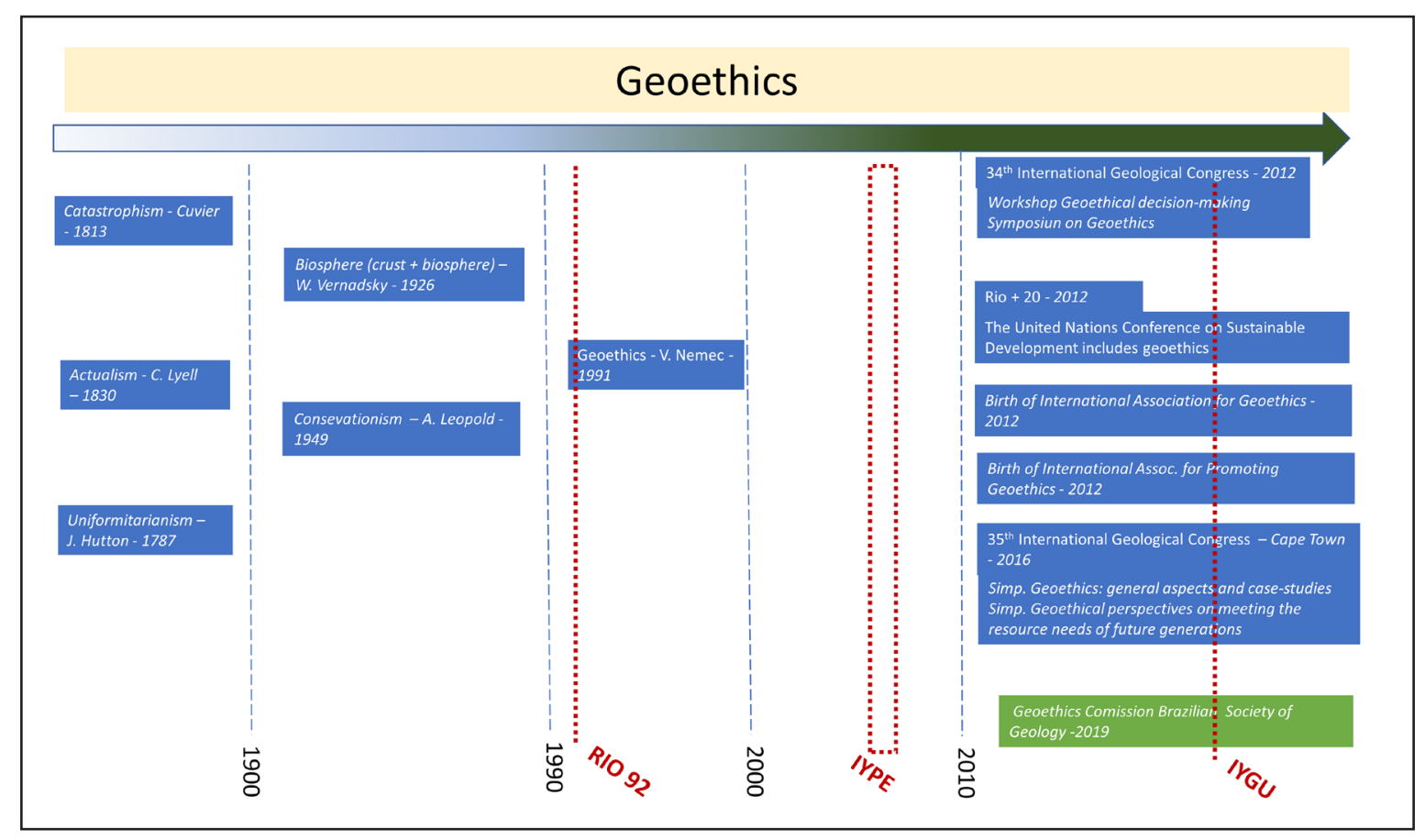

FIGURE 1. Evolution of the concept, applications and milestone events in Geoethics in the world and in Brazil. Rio - 92 United Nations Conference on Environment and Development; IYPE - International Year of Planet Earth; IYGU International Year of Global Understanding. 


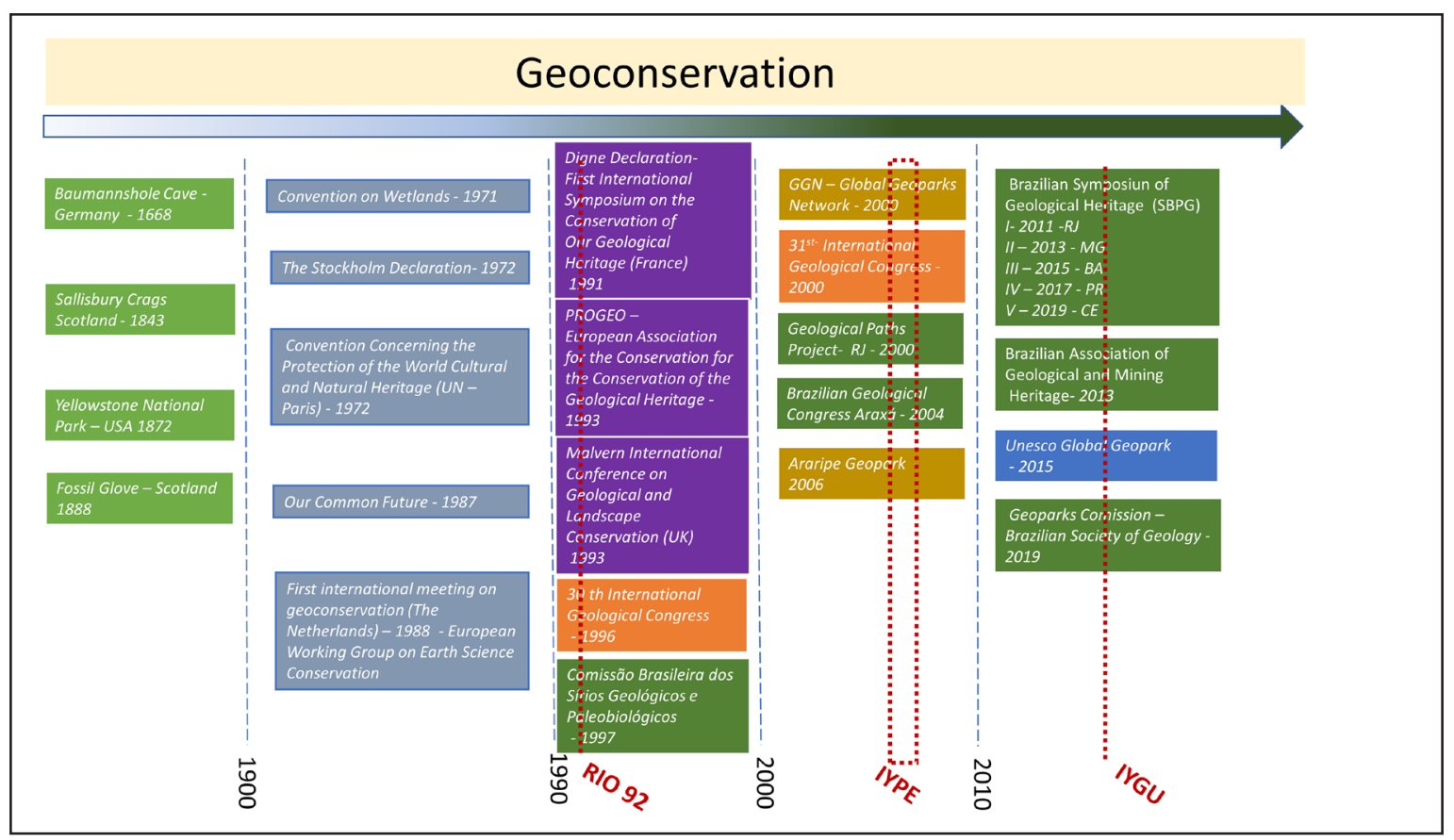

FIGURE 2. Evolution of the concept, applications and milestone events in Geoconservation in the world and in Brazil. Rio - 92 United Nations Conference on Environment and Development; IYPE - International Year of Planet Earth; IYGU International Year of Global Understanding.

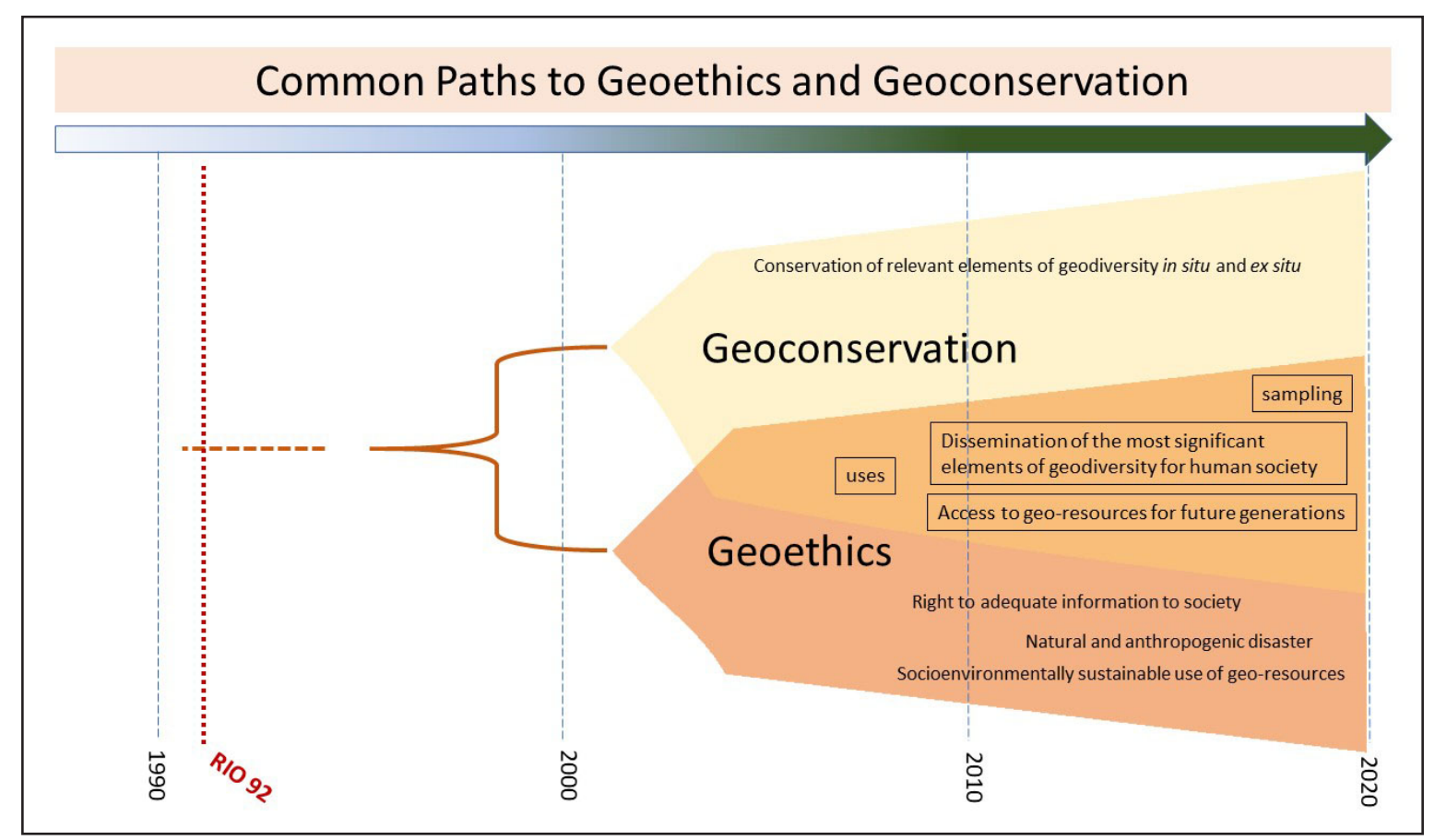

FIGURE 3. Overlap zone between Geoconservation and Geoethics

big cities, whether natural heritage or constructed (FernándezMartínez et al. 2011; Minvielle and Hermelin 2011; Del Lama et al. 2014). It is worth mentioning that the world urban population overtook the rural in 2014 (United Nations 2014) and should reach around $70 \%$ by 2050 (United Nations 2020).

In general, beyond geoconservation, the conducted studies involve geoscientific education and geotourism, associated with urban geoconservation actions (Wrede and Mügge-Bartolović 2012; Del Lama et al. 2014). Catana (2009) proposed formal education programs involving the Arouca Geopark, Portugal, which besides divulging geosciences in formal and informal educational activities, would also involve the community in the management process for the conservation of local geoheritage. "UNESCO Global Geoparks are areas that use the concept of sustainability, value the heritage of Mother Earth and recognize the need to protect it" (UNESCO, 2020).

In Brazil, when referring to areas protected by law, involving the National System of Conservation Units (Sistema Nacional de Unidades de Conservação - SNUC), various categories can be identified within and/or with limits close to urban centers. 
However, little inclusion is identified, on the part of managing bodies, involving the community in programs or actions that translate into shared management, when compared to geoparks (Imbernon et al. 2014).

An example to be cited is observed in the administrative area of Greater London, in which geoconservation is proposed as a possibility for raising awareness on the themes that involve preservation and conservation in large urban centers (Carlsen and Heath 2012).

Examples of this ethical posture for the Earth system can be seen in Bonito (state of Mato Grosso do Sul), in the visitation of the Cavernas do Lago Azul (Blue Lagoon Caves) and in diving in the Formoso River (Boggiani et al. 2007); regulated visitation at The Wave geosite, in Arizona (Antelope Canyon 2017); and the Naica cave of the crystals, in México (Daily JSTOR 2017).

However, beyond the environmental and social discussion lies the necessity for scientists to discuss Geoconservation and Geoethics. This finding passes through data collection to research and attitudes during the fieldwork teaching process (Mansur et al. 2017). It also reaches the construction of an attitude of respect for the planet and other researchers/ teachers that use the same site for their research or teaching in the field. This leads to the need for codes of conduct based on geoethical behavior for companies, universities and professionals.

Butler (2015) heavily criticizes sampling through boreholes carried out on protected sites with heritage value, which he calls "Destructive sampling ethics". He attributes the responsibility for damage to outcrops not only to the researcher but also to the institution to which they belong and the publisher of the journal where the related article and data collection were published.

\section{Final considerations}

With the evolution of thought on nature and human interference, at the end of the 20th century and the beginning of the 21st century, there appeared various concepts that had been maturing and gaining strength with the Rio 92 Conference. Among these concepts are Geoethics and Geoconservation. The argument of the present article is developed based on the relationship between these two areas of knowledge that arose amid the need for new perspectives in the approach of geosciences, triggered, in part, by environmentalist movements.

Based on the analysis of the timelines elaborated from the first steps to the consolidation of concepts, as well as the interpretation of how they are intercepted today, we can see that they have a common origin and an interconnected and interdependent future.

Nowadays, there is no possibility of professional action, whether in industry or academia, in a report or a class in the field, in which these concepts do not need to be placed as part of a responsible posture towards people and the environment. Geoconservation and Geoethics should be immediately added to the training agenda of Geoscience professionals at Brazilian universities, evolving towards dissemination in science popularization projects and natural risk prevention aimed at the public in general.

Geoscientists are responsible for the use and management of the Earth's non-renewable abiotic resources. The guarantee of these resources for future generations makes it necessary to include concepts of Geoethics and Geoconservation in concrete actions, so that the Anthropocene is experienced within a perspective of respect and ethics between people and the immediate and global environment.

\section{Acknowledgments}

The authors would like to thank the reviewers for their time spent on reviewing our manuscript and their comments that improve the text. Paulo de Tarso Amorim Castro and Úrsula Ruchkys de Azevedo would like to thank the National Council for Scientific and Technological Development (CNPq), for research productivity grant 2 . The authors are members of the Geodiversity, Geological Heritage and Geoconservation Research Group (dgp.cnpq.br/dgp/espelhogrupo/0070510 881078351) and Geoethics Research Group (http://dgp.cnpq. br/ dgp/espelhogrupo/229302).

\section{References}

Allan M. 2015. Geotourism: an opportunity to enhance geoethics and boost geoheritage appreciation. In: Peppoloni S., Di Capua G. (eds.) 2015. Geoethics: the Role and Responsibility of Geoscientists. London, Geological Society Special Publications, 419, 25-29. http:// dx.doi.org/10.1144/SP419.20

Antelope Canyon. 2017. How to get a permit for The Wave Arizona. Available on line at: https://antelopecanyon.az/get-permit-wavearizona/ (accessed on 12 July 2019).

Bobrowsky P., Cronin V.S., Di Capua G., Kieffer S.W., Peppoloni S. 2017. The Emerging Field of Geoethics. In: Gundersen L.C (ed.) 2017. Scientific Integrity and Ethics with Applications to the Geosciences. Washington, D.C., John Wiley and Sons. p. 175-212. https://doi. org/10.1002/9781119067825.ch11

Boggiani P.C., Silva O.J., Gallati E.A.B., Gesicki A.L.D., Salles L.O., Lima M.M.E.R. 2007. Definição de capacidade de carga turística das cavernas do monumento natural Gruta do Lago Azul (Bonito, MS). Geociências, 26(4), 333-348. Available on line at: https://www.periodicos.rc.biblioteca. unesp.br/index.php/geociencias/article/view/1798

Brilha J. 2016. Inventory and Quantitative Assessment of Geosites and Geodiversity Sites: a Review. Geoheritage, 8, 119-134. https://doi. org/10.1007/s12371-014-0139-3

Burek C.V., Hope M. 2006. The use of town trails in raising awareness of urban geodiversity. In: International Association for Engineering Geology Congress, 10. $7 \mathrm{p}$.

Butler R. 2015. Destructive sampling ethics. Nature Geoscience, 8, 817818. https://doi.org/10.1038/ngeo2572

Carcavilla Urquí L., López Martínez J., Durán Valsero J.J. 2007. Patrimonio geológico y geodiversidad: investigación, conservación, gestión y relación con los espacios naturales protegidos. Serie Cuadernos del Museo Geominero, 7. Madrid, Instituto Geológico y Minero de España, 360p.

Carlsen J., Heath P. 2012. Green infrastructure and open environments: London's foundations: protecting the geodiversity of the capital: supplementary planning guidance. London, Great London Authority, $261 \mathrm{p}$.

Carvalho M. 1991. O que é natureza. Coleção Primeiros Passos. São Paulo, Brasiliense, 82p.

Castro J. E. 2019. X-disciplinariedades y bifurcaciones en los estudios sobre el agua. In: Castro J.E., Kohan G., Roma A. Ruggerio C. (eds). Territorialidades del agua: conocimiento y acción para construir el futuro que queremos. Buenos Aires, Ediciones Ciccus. p. 18-47.

Castro P.T.A., Ruchkys U.A. 2017. Iniciativas sobre patrimônio geológico e temas correlatos no Quadrilátero Ferrífero, MG. Caderno de Geografia, 27, special number 2, 314-331. https://doi.org/10.5752/ P.2318-2962.2017v27nesp2p314

Catana M.M. 2009. Os Programas Educativos do Geopark Naturtejo: ensinar e aprender geociências em rotas, geomonumentos, museus e na escola. In: Neto de Carvalho C., Rodrigues J. C., Jacinto A. (eds.). Geoturismo e Desenvolvimento Local. Idanha-a-Nova, Câmara Municipal de Idanha-a-Nova, p.291-307.

Daily JSTOR. 2017. Exploring Mexico's otherworldly cave of crystals. Available on line at: https://daily.jstor.org/exploring-mexicos- 
otherworldly-cave-of-crystals/ (accessed on 12 July 2019).

Del Lama E.A., Bacci D.C., Martins L., Garcia M.G.M., Dehira L.K. 2014. Urban Geotourism and the Old Centre of São Paulo City, Brazil. Geoheritage, 7, 147-164. https://doi.org/10.1007/s12371-014-0119-7

Di Capua G., Peppoloni S. 2019. Defining geoethics. International Association for Promoting Geoethics. Available on line at: https://www. geoethics.org/ (acessed on 18 October 2020).

Drąsutè V., Drąsutis S., Corradi S., Kelpšaitè N. 2019. Social responsibility and ethical attitude on the media. In: Vasconcelos C., Schneider-Vo $\beta$ S. Peppoloni S. (eds.). Teaching Geoethics: Resources for Higher Education. Porto, Universidade do Porto, p. 32-41.

Fernández Martínez E., Castaño de Luis R., García Parada L., Molero Guerra J., García Ortiz de Landaluce E. 2011. Viejas y nuevas formas de divulgar el patrimonio paleontológico: el caso de los Fósiles Urbanos de León. In: Fernández-Martínez E., Castaño de Luis, R. (eds). Avances y retos en la conservación del Patrimonio Geológico en España: Actas de la IX Reunión Nacional de la Comisión de Patrimonio Geológico (Sociedad Geológica de España). León: Área de Publicaciones, Universidad de León, 125-132. Available on line at: https://buleria.unileon.es/handle/10612/10370

Fontana R. C., Menegat R., Mizusaki A. M. P. 2015. Geoconservação em grandes cidades e proposição dos itinerários geológicos de Porto Alegre: contribuições metodológicas para valoração integrada de unidades geológicas. Geociências, 34(4), 897-918.

Gray M. 2019. Geodiversity, geoheritage and geoconservation for society. International Journal of Geoheritage and Parks, 7(4), 226-236. https:// doi.org/10.1016/j.ijgeop.2019.11.001

Henriques M.H., dos Reis R.P., Brilha J., Mota T. 2011. Geoconservation as an emerging geoscience. Geoheritage, 3, 117-128. https://doi. org/10.1007/s12371-011-0039-8

Imbernon R. A. L., Oliveira C. N., Gonçalves P. W. 2014. Environmental Education within Protected Areas: a Comparative Study between the Conservation Unity in Brazil and the Geoparks in Portugal. Journal of Agriculture and Environmental Sciences, 3(3), 105-124. http://dx.doi. org/10.15640/jaes.v3n3a9

International Declaration of the Rights of the Memory of the Earth: Digne le Bain Declaration. 1991. In: International Symposium on the Conservation of Geological Heritage,1. Available on line at: http:// www.progeo.ngo/downloads/DIGNE DECLARATION.pdf

Leopold A. 1949. A Sand County Almanac: and Sketches Here and There. New York, Oxford University Press, 240 p.

Lovelock J. 1995. Gaia: um novo olhar sobre a vida na Terra. Lisboa, Edições 70, 168p.

Mansur K. L., Ponciano L.C.M.O, Castro A.R.S.F. 2017. Contributions to a Brazilian Code of Conduct for Fieldwork in Geology: an approach based on Geoconservation and Geoethics. Anais da Academia Brasileira de Ciências, 89(1), 431-444. https://doi.org/10.1590/0001$\underline{3765201720170002}$

Mansur K.L. 2018. Patrimônio Geológico, Geoturismo e Geoconservação: uma Abordagem da Geodiversidade pela Vertente Geológica. In: Guerra A.J.T., Jorge M.C.O. (eds.). Geoturismo, geodiversidade e geoconservação: abordagens geográficas e geológicas. São Paulo, Oficina dos Textos. p. 1-49.

Minvielle C.A., Hermelin M. 2011. Geometro or How to Discover a Valley's Geomorphology by an Integrated Transportation System in Medellin (Colombia). Geoheritage, 3,73-81. https://doi.org/10.1007/s12371$\underline{010-0017-6}$

Mogk D., Geissman J. W., Bruckner M. Z. 2018. Teaching Geoethics Across the Geoscience Curriculum: Why, When, What, How, and
Where? In: Gundersen L. C. (ed). Scientific Integrity and Ethics in the Geosciences. Hoboken, American Geophisical Union. p. 231-265. https://doi.org/10.1002/9781119067825.ch13

Mooney H. A., Ehrlich P. R. 1997. Ecosystem services: A fragmentary history. In: Daily G. C. (ed.). Nature's services: Societal dependence on natural ecosystems. Washington D.C, Island Press. p. 11-19.

Mulder E.F.J., Nield T., Derbyshire E. 2006. The International Year of Planet Earth (2007-2009): Earth Sciences for Society. Episodes, 29(2), 82-86. https://doi.org/10.18814/epiiugs/2006/v29i2/001

Penkaitis G., Imbernon R.A.L., Vasconcelos C.M.S. 2020. Pagamento por Serviços Ambientais (PSA): o papel do conhecimento geocientífico no protagonismo social. Terræ Didatica, 16, 1-12. https://doi. org/10.20396/td.v16i0.8659281

Peppoloni S., Di Capua G. 2012. Geoethics and geological culture: awareness, responsibility and challenges. Annals of Geophysics, 55(3), 335-341. https://doi.org/10.4401/ag-6099.

Peppoloni S., Di Capua G. 2015. The meaning of Geoethics. In: Peppoloni S., Wyss M. (eds.). Geoethics: ethical challenges and case studies in Earth Science. Waltham, Elsevier. https://doi.org/10.1016/B978-0-12799935-7.00001-0

Roser M. 2019. Future Population Growth. Available on line at: https:// ourworldindata.org/future-population-growth/ (accessed on 18 August 2020).

Ruchkys U. A., Oliveira C.K R., Jardim H.L., Jorge L.M.S. 2018. Abordagem metodológica da geodiversidade e temas correlatos em Geossistemas Ferruginosos. Caderno de Geografia, 28(1), 1-17. https://doi.org/10.5752/P.2318-2962.2018v28nespp1

Soares M.L.A. 2008. Da evolução da concepção de natureza e de homem na ambiência de uma educação ambiental crítica. Reunião Anual da ANPED, 31. Available on line at: https://anped.org.br/ biblioteca/item/da-evolucao-da-concepcao-de-natureza-e-dehomem-na-ambiencia-de-uma-educacao/(acessed on 18 October 2020)

Stephens M. 2020. Geoconservation for Sustainable Development. Springer Nature Switzerland AG 2020. In: W. Leal Filho W., Azul A. M., Brandli L., Lange Salvia A., Wall T. (eds.). Life on Land: Encyclopedia of the UN Sustainable Development Goals. Springer, Cham. https:// doi.org/10.1007/978-3-319-71065-5 140-1

Subcommission on Quaternary Stratigraphy. 2019. Results of binding vote by AWG: Released 21st May 2019. Available on line at: http:// quaternary.stratigraphy.org/working-groups/anthropocene/

Unesco. 2020. UNESCO Global Geoparks \& Geoconservation. Available on line at: http://www.unesco.org/new/en/natural-sciences/ environment/earth-sciences/unesco-global-geoparks/top-10-focusareas/geoconservation

United Nations. 2014. World Populations Prospects 2014. Available on line at: https://population.un.org/wup/Publications / (accessed on 18 October 2020).

United Nations. 2020. World Populations Prospects 2019. Available on line at: https://population.un.org/wpp / (accessed on 18 October 2020).

Werlen B., Osterbeek L., Henriques M. H. 2016. 2016 International Year of Global Understanding: building bridges between global thinking and local actions. Episodes, 39(4), 604-611. https://doi.org/10.18814/ epiiugs/2016/v39i4/103894

World Forum on Natural Capital. 2017. What is natural capital? Available on line at: https://naturalcapitalforum.com/about/

Wrede V., Mügge-Bartolović V. 2012. GeoRoute Ruhr-a Network of Geotrails in the Ruhr Area National GeoPark, Germany. Geoheritage, 4, 109-114. https://doi.org/10.1007/s12371-012-0057-1 
